\title{
Standing tall: Posture, ethics and emotions in Dobu
}

\author{
Susanne Kuehling
}

The language of emotions can be revealing, especially when words and expressions relate directly to body imagery. In this chapter, the body is examined as a site of moral judgements. Moral conduct, when discursively framed in body imagery, maps out an individual's options of acting and, perhaps more clearly among Austronesians, leads to almost permanent self-awareness. I argue in this chapter that 'emotion words'spatial expressions of internal processes-are not merely conventional metaphors, but also deeply embedded in local ethics, sense of place and the concept of personhood. For an emotional geography among Austronesians, language is a key (Bellwood et al. 1995: 3; Fox 1995: 215). Linguistic analysis of features such as the common prefixation of emotion words as an Austronesian strategy (body + emotion) may be a yielding path (Huang 2002), but a large body of data is required for the diverse array of Austronesian-speaking societies. According to Pawley, even within the subgroup of Proto-Oceanic there are 'at least five distinct cognate sets ... meaning something like "person, human being"” (1985: 93). Austronesians share the experience of being islanders and sailors-a world view based on island experience. The 'noble' posture and the friendliness of Pacific Islanders are legendary, noted by visitors since the early European explorers and missionaries. 
As an ethnographic field of study, emotions are challenging, as we too easily assume that, as humans, we all feel the same way and therefore understand our inner states similarly. Seemingly universal emotion words are often constructed as if a sensation, thought or feeling were localised at a specific spot inside the human body. English speakers, for example, construct the heart as the locus for love and the head as the place of thought. While widespread and seemingly intuitive, the clustering of 'inner states' differs between societies, as the mapping of inner states reflects social principles and patterns that are complexly tied to local ontologies. As ideological practices, emotion states are used in moral discourse and deserve more attention (Lutz 1988: 10). Yet so far, as Hereniko critiques, academic texts express our privilege of written sources over performance in Pacific cultures. The messages conveyed through body language:

are not overt, and often go unnoticed by academics, who are more adept at reading between the lines on a page than reading the message implicit in the kinds of costumes being worn, the way space is negotiated, the arrangement of dancers, the hand, feet, and facial movements, and other elements of performance that embody a culture's aesthetics and values. (Hereniko 2000: 88)

Based on linguistic data, I suggest that the Austronesian concept of personhood includes a private, 'inside' location where thoughts and feelings are experienced and processed, stored and selectively displayed. Exactly where this is located is open to interpretation and varies even between neighbouring Austronesian societies. Tsou speakers claim to locate knowledge in the ear, as Huang reports (2002: 173). Dobu Islanders locate their thinking/feeling (nua) deep inside themselves. To these people, as for other Austronesians, there is no clear distinction between emotions and thought processes: nua is the secret area where spells and strategies, feelings, fantasies and memories are located. This 'inside' is further compartmentalised in Dobu, where anger and love are, respectively, constructed as located in the stomach (gamwa) and liver (ate). It is regarded as virtuous to self-censor one's nua, and individuals strive to appear as 'good' persons in spite of their deeper feelings/thoughts. Generally, a wise person keeps these inside locations under vigilant control (Kuehling 2005; Weiner 1984). Such self-discipline is expressed both verbally and literally in a straight posture. Being happy_literally having a straight back-emplaces an emotion as a sociolinguistic pointer of virtue. People control their posture, as they know that failure to keep a straight back is perceived as laziness (a bent back). Overexcitement, a negatively 
classified feeling, is linguistically constructed as having an overly straight spine, and only the middle ground — a nicely straight back — comes across as evidence of a happy, industrious, well-rounded person.

My data stem from long-term fieldwork and are grounded in intersubjective relationships based on mutual friendship and/or constructed kinship with Dobu Islanders of south-eastern Papua New Guinea. What I here gloss as happiness and laziness are based on the dictionaries (Dixon n.d.: 82; Lithgow 1984: 20) and established use of language by English-speaking islanders. These categories will be discussed in detail here, as they allow us to demonstrate how the corresponding posture can be read as a moral statement. Dobu Islanders keep their back straight and smile not only as a result of feeling happy, but also as a way to perform this positively valued mixture of sentiments to be acknowledged as a 'happy person' by others (and, implicitly, not be regarded as 'lazy' or 'overexcited'). A (German) physiotherapist once told me that this was the right posture to feel proud and free, 'like a queen'. While this may well be an effect of this posture, Dobu Islanders have no intention to 'feel like a queen'. Their upright posture and friendly smile have wider implications than personal feelings, and this may well be specific to an Austronesian way of being in the world, as I will demonstrate here. I will also pay attention to the more subtle and subjective forms of communication, such as body language, to push my sociolinguistic entry point to the moral dimension of happiness and laziness and, ultimately, to ponder how this relates to personhood. Of course, not everyone follows ethical principles in the same way, as Dernbach has pointed out (2005: 333-4), but once I was fluent in the vernacular, I believe I picked up the views and, after a year of residence, shared the feelings and 'understood' some of the islanders in personal, empathetic ways. Here is an example of my learning process:

Mary had a huge sore on her leg, looking as if a generous tablespoon of strawberry jam had been spread on her thigh. It was so big that the largest band aid was way too small. My British colleague, who pitied the young woman, asked me for gauze, explaining that the wound needed to be at least covered to keep the flies and dust out. Since I had not brought any supplies, he wandered off to look elsewhere, leaving me with Sandra, the in-law from Chimbu who had a somewhat outsider's point of view and was refreshingly open when describing sensitive topics. Sandra smiled and showed me a circular scar on her own thigh, explaining that this had been a sore just like Mary's, and that it took two days to heal completely when her period of punishment was deemed over by the senior villagers. 'They spoke over water, poured it over the sore, already it began 
to heal', Sandra remembered. Mary, she added, had not been sufficiently cooperative in the preparations of the feast (that the British colleague and I were observing in Miadeba, Normanby Island, in December 1992). 'She just spent her time in her garden with her husband while we were all working so hard ... this is where the sore comes from and this is why we don't feel sorry for her'. Clearly, at that time, I did not share Sandra's way of looking at pain, but while I did feel sorry for Mary, I had not thought of dressing the wound, knowing well that there are many local ways of doing so if desired, and only providing my very limited medical services when directly asked. The conversation brought the lesson home explicitly_people may choose to show 'no pain' in spite of a gaping wound, and Mary was actually repenting, improving her moral standing, as she completed her chores with an eager posture in spite of the flies eating at her flesh. (Fieldnotes, 17 November 1992; names changed)

\section{A person is an island in a sea of people}

Recently, scholars have argued for place-based identities of Austronesians (see Fox 1997a, 1997b)_for example, in Vanuatu (Bolton 1999; Hess 2009), engaging in a debate on shared identities or 'dividual' personhood (Macintyre 1995; Mosko 2009; Strathern 1988). My discussion builds on the understanding that persons and places are deeply linked. Spatial metaphors are at the junction of self-experience and self-expression: as persons, Austronesians may experience themselves in a more connected ('dividual') way, as members of groups and representatives for their lineage in time and space, yet there can be no doubt that, at the end of the day, we feel the pain of our individual body and eventually will suffer its death.

Epeli Hau'ofa has argued that the islands of Oceania should be seen as linked, not separated, by the ocean. In a similar way, I propose, persons can be seen as islands, connected by the environment but separated by individual desires and strategies that are located inside each body. This linguistic geography of the person, I believe, leads to a layered model of intimacy-connected through the environment of water, air and ground - and may serve as an illustration while positioning my argument in a larger framework and, perhaps, within Austronesian social memory and protolanguage (see Ross et al. 2003: 88).

Imagine yourself on a canoe, slowly approaching a Pacific island. Your first impression speaks to the prosperity and fertility of a place. You see a beach or mangroves, the canopy of trees, smoke from a settlement. The 'skin' of an island, just like the skin of a person, allows a surface reckoning. 
The outsider's gaze provides knowledge about season and surrounding islands, plants and architecture, just as a view of a person's skin at first encounter, their shape, flesh and hair, can reveal information about their age, health and wealth. This first impression is often misleading: an island may look like paradise or a person may appear nice, but a closer look reveals both agreeable and unpleasant aspects.

Arriving on the beach, entering a village, a clearer, morally painted picture emerges. Are the people content, are they hardworking, well behaved and generous? Is this a 'good' place (see Kahn 1996)? Being part of village life provides insights into the moral standing of individuals, glimpses of the hidden inside in spite of all efforts to keep a 'straight face' — as English speakers would say. Dobu speakers locate this effort in the back as the locus for performance as a self-disciplined, hardworking, motivated, moral person, as, like facial expressions, the back can be manipulated. I have seen feverish people sitting on their verandah all day, without back support, with a straight spine. Friends who had stayed up all night never displayed their tiredness when asked to help with a chore; people who had asked me for painkillers because of severe back pain still maintained a straight posture as we walked to pick up some pills. To control one's posture, to keep a straight back, appears to be an indication of personal qualities: a dignified, calm, hardworking, helpful person is the ideal. Jason Throop's work on pain in Yap is comparable with the case on Dobu: controlling pain is evidence of being a 'good' person. Women giving birth without a sound, under their house, are exemplary, as they do not attract envious spirits, witches, confused ghosts or other airborne creatures of the night. The settlement, like the posture of a person, is a public stage where social relations and personal virtues are performed.

Moving any further than the village is regarded as impolite and intrusive, because the inside of houses (Fox 1997a; Rensel and Rodman 1997) and the central region of an island are private spaces in many Austronesian societies. The English metaphors of the 'heart' of an island and as the locus of emotion almost catch the Austronesian construction of an intimate 'inside' place in the body, where thinking and feeling happen. Closed to the outsider, this 'inside' is opaque, not publicly accessible, yet always in danger of being violated. Trespassing could result in death, as island space may be defended by an enraged landowner who swings a machete, and sorcery practices involve intruding in a victim's 'inside'. Going to the inside of an island is only acceptable when permission to trespass is granted, as the bush, gardens and graveyards are private spaces. Places and persons are protected by ethical principles of privacy. Dobu people are 
required to 'stay at home and mind their own business', to refrain from 'useless wandering' (miabaula) and to work for others in a tireless fashion (gwaunua). The ethic of 'self-discipline' (alamai'ita, lit.: 'to carry a burden tightly and continuously') enjoins that inner feelings are kept to oneself, no matter whether they are valued negatively—such as greed, lust, anger, pride, envy, shame — or positively — such as joy, sympathy or the feeling of being 'just right and filled up with nice food' (see Kuehling 2005: 33-6; see also Edoni 1989). Many spatial metaphors draw an image of a centre with some mobility that requires regulating attention; thinking/ feeling (nua) may, for example, be 'descending' to refer to humbleness (nuamwauta), it may be 'climbing up' when someone is boastful (nuatue), 'heavy' from worries (nuamwau), 'calm and quiet' when someone is at peace (nuasiwalowa), 'wandering aimlessly' when someone is confused (nuaiyowana) or it may be 'returning like a new plant from a seed' (Edoni 1989: 37) when a person is in a retrospective mood (nua'ila). It is impolite in most situations to mention inner feelings, just as it is regarded as overly inquisitive to ask about the inside of a house or about details of someone's garden. To be openly angry, yelling at an adult or even banging one's fist on a verandah, is offensive. 'My inside is out [nuagu i out], my liver is exploding [ategu i pisali]!' snarled the old man when he learned that his lavish gift assembly was inappropriate for the occasion of the feast that was performed. Trying to conceal one's inside, even when angry, leads some people to wear sunglasses when they plan a harangue (which is rare and perceived as embarrassing by everybody concerned). One's inside, in Dobu, tries to get out of its opacity and live out antisocial desires. Feelings such as anger, greed, envy, pain or the urge to just let go, relax one's back and stay away from tiresome work need to be kept under tight control as it is not socially acceptable to be intrusive, whining or lazy (gwautoyasa, lit.: 'to have a bent back').

Figure 7.1 distinguishes the three layers of intimacy proposed here: the beach of an island likened to the skin as the outward representation of the person, the inside of an island as a private space likened to the thinking/ feeling located as nua inside a body and the intermediate zone of village life, where virtues and vices are negotiated and form the moral base of daily life in a small community. In Dobu imagery, this intermediate dimension is linked to the back, which is controlled by a person's willpower unless it slips out of attention, contributing to a mixed performance that is negotiated in terms of 'happiness' and 'laziness', a 'straight' and a 'bent' back. This image is encoded in gift exchanges and moral judgement, bridging wants and deeds. 

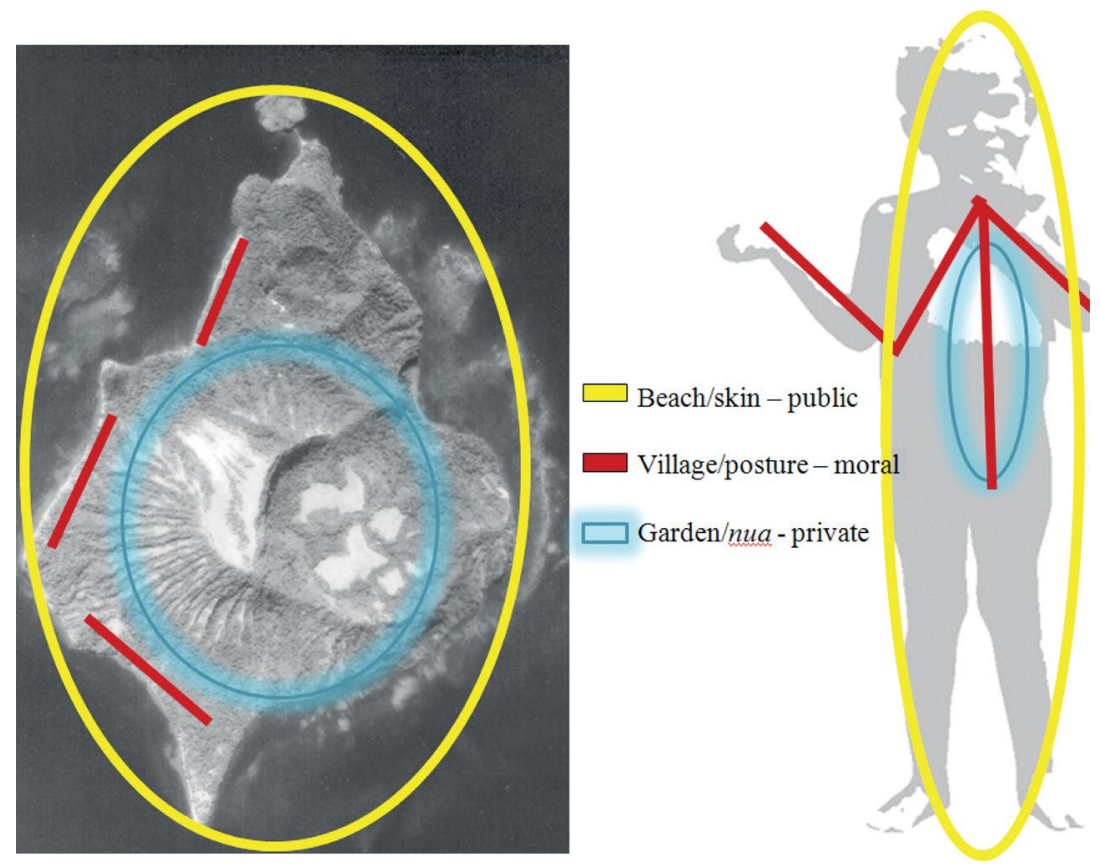

Figure 7.1 Mapping intimacy

Source: Author's figure, overlaid on aerial image from the National Mapping Bureau of Papua New Guinea.

\section{Don't slouch! Be happy!}

Restricted spatially and interpersonally, everyday life happens at very few places and around a small number of people, creating strong social pressure to conform and to appear as 'good', hardworking and generous. Annette Weiner's description of Trobriand Islanders' need to protect their 'inside' compares with the Dobu construction, including a general notion that 'truth is being created anew in the telling or the giving' (1984: 163). I have argued elsewhere that the atmosphere of surveillance in a Dobuan village is not too different to that in the Panopticon-British architect Jeremy Bentham's famous model prison (Kuehling 2005: 138-42). The intensity of constant social control is particularly obvious when individuals are expected to share what they wish to keep for themselves, as Dobu ethics favour an egalitarian distribution of wealth (so that 'everybody can have a straight back'). The vernacular term for happiness, gwauso'ala, literally means that the 'back' (gwau) can 'carry' (ala) its weight and keep the body 
straight. Linguistically, the term is constructed with an alienable possessive prefix—ma igu gwauso'ala ('with my happiness')—suggesting the partly external nature of this feeling. It can also be used as a verb-i gwauso'ala ('he/she is happy') — as often found in stories.

The back is part of a number of emotion terms serving as a metaphor for upright posture (suggesting a strong, happy or excited feeling) or for a bent and weak posture (suggesting a lazy, bored or listless state). I have elsewhere discussed the use of body parts in emotion words (Kuehling 2005: 38).

Table 7.1 Posture and emotion

\begin{tabular}{|l|l|l|}
\hline Emotion word & Literal meaning & 'Translation' \\
\hline gwauso'ala & back-carry & happy, satisfied, relieved, gay, glad \\
\hline gwaunua & back-thinking/feeling & hardworking \\
\hline gwau'a'ala & back-very-straight & excited \\
\hline $\begin{array}{l}\text { gwaugu'itoyase, also } \\
\text { guitoyasa, gwautoyasa }\end{array}$ & my back is stiff & lazy, unmotivated, bored, listless \\
\hline
\end{tabular}

Note: See also Kuehling (2005: 287) As a metaphor, the back (gwau) is constructed as the site where the inside becomes visible during episodes of hard work (gwaunua, lit.: 'back-inside'). The spine gives away hidden feelings and thoughts when people interpret one another's posture. A person stands either 'straight' (gwauso'ala, gwau'ala) or 'bent over' (gwautoyasa). The former is an expression of eagerness to work hard (gwaunua), of happiness and communality, while the latter stands for the opposite: laziness, exhaustion, sickness and, ultimately, selfishness. The posture of a person, hence, is a moral statement, leading people to control the way they walk and sit and to critically observe how others carry themselves. Women-used to carrying heavy loads on their heads-are known to walk with a straight back without showing signs of exhaustion as they hold a toddler on their hip and climb the muddy paths to the garden for their daily work. No woman complains about the pain, just as they take pride in giving birth silently. Likewise, men who deliver a large bundle of firewood will modestly smile when praised for their alamai'ita ('self-discipline'), pretending that it was not painful to bring those logs from a distant garden. A good person is happy, not lazy; this implies holding the spine straight and moving energetically.

The social emotion of happiness, expressed as a matter of posture, deserves more attention and context. To be happy, relaxed and generally at ease is a desired emotional state to Dobu Islanders (as for all humans, I believe). Sadly, it seems so hard to reach such balance, and Dobu Islanders certainly do not live in a state of harmony. Their happiness is the hard-earned result of self-discipline, generosity, respect and labour. I have argued that, in Dobu society, this state can only be achieved 'when the balance between giving and keeping is maintained' (Kuehling 2005: 70). A happy person is strong, stands straight in a dignified manner and works hard-no wonder 'happiness' (gwauso'ala) is a welcome character trait. Those happy 
moments during fieldwork, when I sat with friends and shared a sense of ease and relaxation, are the basis of the following description of the imagery of happiness to the islanders with whom I lived from 1992 to 1994 and whom I keep visiting.

In daily life, happiness arises from various pleasures, such as sensual experiences of the environment. Basking in the morning sun (eyala) is a delightful way to shake off the coldness of the night. Other pleasures include sitting in a slight breeze on a hot day (siwalowa), seeing the full moon lighting up the hamlet, feeling a gentle rain after the planting of the yams, seeing a magnificent sunrise after a long night of feasting, or tasting a fresh mango and feeling its juice all over one's face and hands. In terms of social life, images of joyful family life come to mind, of parents or peers sitting and sharing food and betel nuts with their children, sending them on little missions to the neighbours or into the kitchen, watching the progress of their babies and telling stories about everyday incidents. Being at ease includes a 'good conscience' ( $a$-lotona bobo'a-; in the sense of 'good behaviour': $i$ - bubuna bobo'a-) or a 'good name' ( $i$ - ale bobo'a-). A happy person is healthy, has enough food and objects of wealth and a manageable number of reliable relatives, friends and exchange partners.

Happiness and friendship can be heard from a distance at times-for example, when expressed by a certain way of laughing together that ends with an exclamation of ' $h a i$ ' in a higher pitch. This is called losaila (lit.: 'to tie it up' or 'to wind it up'). Happiness in women is associated with the sound of cheerful chatter, with losaila exclamations; it is characteristic of youths on the beach at sunset or hamlet sisters on a shaded platform watching their toddlers play. Small gifts, such as betel nuts, tobacco and assistance in daily chores, are evidence of a person's ability to 'keep a straight back', to be happy and industrious yet humble and respectful. Such happiness is framed by the absence (or denial) of such internal states as anger, shame, lust, pain, hunger, greed or pride (Kuehling 2005: 90). Apart from losaila, happiness is not displayed conspicuously; as such, 'showing off' is despised as a sign of weakness and lack of self-discipline. Happiness is recognised as an emotion, attitude, character trait and social skill; it is a telling sign that a person adheres to the principal ethics. A person who bears no grudges when asked for a small gift, who is willing to form friendships, is praised as oboboma alena - a genuinely generous character. A happy person can suffer bodily pain and frustrations, share food and remain affable while hungry_all reasons to praise his or her alamai'ita ('self-discipline'). A young, happy person is in a better position 
to cultivate strong ties with senior people by giving them 'small gifts' with a happy face and an appropriately friendly and obedient demeanour when interacting with them. This kind of conduct shows 'respect'; a straight back never implies a towering attitude, but an energetic eagerness and joyful approach to the tasks at hand.

The back should not be too straight, however, as an overly proud performance is looked down on as 'showing off (mokolowai or gagasa). To be openly excited (gwau'a'ala) is evidence of a poorly restricted mind that rises too high (nua'tue). Wearing bright colours, dancing and singing out of context, shouting and being too talkative are discouraged in children at an early age-simultaneously with their training to bend forward and mutter 'excuse me' or ya mai ('I am coming') when passing other people at close distance. Little girls learn to balance a basket on their heads and walk confidently with a straight posture; little boys are encouraged to carry burdens on their shoulder - both genders are praised when they show no pain or fatigue (Oh, alamai ita!: 'Oh, self-discipline!').

Life can be exhausting on small tropical islands, when the humidity is high and the sun burns mercilessly or when it rains and the paths are slippery and people feel cold. Endemic malaria and other diseases cause weakness and death, medicine is often unavailable or ineffective and household chores are plentiful in a world without plumbing and electricity. Sickness of the body, a 'heavy inside' (nuamwau) due to conflicts, as well as sorcery-induced debilitation, are normal elements of daily life that should be kept 'inside'. I was certainly fooled by the effortless-seeming work of the women when I was on the island. Later, with my own toddler, I returned to Dobu and complained to my friends that it looked a lot easier when they were parenting. Every time I said this, the proud answer of the mothers from Dobu was the same: 'It is hard work to raise a child, but we don't show it.' When I was tired from running after my 20-month-old son and complained about it, I was performing a very dimdim ('Western') way of responding to the challenges of motherhood, but my friends gracefully overlooked my blunder.

The only occasions when I experienced laziness as an accepted and publicly displayed state were during mourning, when receiving a large gift or as a result of the social syndrome called gwasa (or nadiwala). Gwasa (a 'social hangover') is caused by the departure of an overnight visitor or family member. A gwasa infestation at a place makes it unsafe to do any physical work and one can often see villagers sitting idly on their platforms, complaining about so-and-so who gave them this gwasa 'while 
we are in the middle of the [gardening] season'. Having gwasa can be constructed as 'work', as suffering because of hospitality, but other reasons for idleness mirror selfishness. I remember mentioning that I was feeling sick (leoasa), but received the answer that I was in fact down with 'gwasa. We all have it' (see below). Feeling admittedly lazy is acceptable only as a comment between friends while on some tiresome project, not as an explanation for days of sleep.

\section{Emotions of exchange: Staging one's back}

Work becomes most intense when mortuary ritual needs to be performed, when visitors are hosted or other exchange events (marriage, apologetic gifts, kula or gift exchange) take place. Raw yams of high quality (bebai), protein (anina), pork (bawe) and various gifts of lower value are assembled, paraded, set on the ground, thrown down from a platform or publicly prepared and served with decorum. Being a giver during these occasions is licence to be louder and bolder than usual, standing taller and more assertive than at any other time. The act of giving is a register of dominance, while the role of the receiver is characterised by a lower posture, which includes a bent spine and a low voice. A previous gift can legitimise even anger and, during mortuary feasting, when gifts are thrown down from a high platform to a crowd during une, it may be that a large gift comes with a humiliating speech (see Kuehling 2005: Ch. 8).

An embarrassed-looking receiver of a gift may well be scheming about how to assemble a counter gift that will provide an opportunity for an equally bossy response. These roles require self-discipline and temporarily overrule the display of individual virtue; an industrious person with a sunny disposition (and a straight spine) will nevertheless display a body language of lower status when receiving a valuable gift. Since public giftgiving is usually performed by senior men (after counselling by the senior women in most cases I witnessed), it is interesting to observe how a big man bends over, seemingly under the shame and obligation that the act of receiving involves. In everyday life, respectful bending is practised when walking past senior people, as a lower status demands a lower posture and it is seen as impolite to tower over or walk between people who are talking with one another. Respectful bending, unlike lazy bending of the spine, speaks to a humble personality and is valued positively. 
While an opportunity to display virtue, exchange rituals and events are also the time to show vice. During the preparation of a feast, as well as the routine of everyday life, there is almost always someone who is to blame for being lazy, slow, disobedient, adulterous and generally not eager to cooperate. The islanders often use the back for their rhetoric strategies-a convenient point of reference that is freely accessible for all to see. There are many ways to describe the strategies of exchange and the ethical principle of hard work ('back-mind', gwaunua; more generally, paisewa), but one common way is to say that a person is lazy (gwautoyasa) or happy (gwausoala) (see Kuehling 2017a: 219).

In the confidential negotiations of kula exchange, the term gwauso'ala is frequently used: 'if you make me happy today, I will make you happy later and we will both be happier than before' (Kuehling 2005: $210 \mathrm{ff}$.). The Trobriand writer and businessman John Kasaipwalova, following the tradition of sweet-talking an audience by evoking an image of straight spines and bright smiles, called the kula a 'development corporation' to 'further human happiness' (1974: 454; Kuehling 2005: 174; 2017b: 203). Kula exchange is certainly endowed with the power of creating happiness. My informants stated that hospitality, travel opportunities and the joy of receiving valuables were the 'profit' and, perhaps, the raison d'être of today's kula circuits. Going on a kula journey is an occasion to feel happiness:

We all were hungry and thirsty, wanting to bathe and rest. Quietly, we approached the house. I felt unwelcome under the shy gaze of the children who were not used to me (a dimdim, after all, they reminded me of my whiteness that was no longer a sensation on Dobu). The wife of our partner came rushing from the garden, alerted by some children. Her husband, she explained, was paying a visit and expected back in the evening. We sat down in the shade of the veranda, chewed betel, smoked and waited—again. In the kitchen hut, girls started to peel yams. We watched the children chasing a chicken and felt happy about the prospect of eating it. (Fieldnotes, 24 May 1993; see Kuehling 2005: 207)

Alexander Meleodi, a kula master from Dobu, gave the example of a gift called eyabala ('looking across', 'passing on') that begs for a specific kula valuable. It consists of a basket (kwalisi) of raw yams and other seasonal food that is sent to the kula partner through a middleman. The recipient should give a bagi or mwali to the deliverer, who has to pass it on to the sender of the eyabala. At some later opportunity, a matching valuable has to be returned, but the value of the basket of food remains unbalanced; 
it was meant to cause happiness—and friendship (Kuehling 2005: 195). Alexander pointed out how nice it was to receive such a thoughtfully composed basket out of the blue and 'for free'. Receiving a kula object of high value requires a 'lazy' posture, controlling the joy as perfectly as possible.

Mortuary ritual is another occasion for happiness for the many participants at the margin of these week-long events. Only the principal mourners are heavily involved in the suffering of death and the staging of suffering; they have to bend their backs, cover their heads, hush their voices and refrain from 'happiness' out of love and respect, and are only slowly ritually returned to a happier state when their time of mourning restrictions is terminated. The resident group that organises a mortuary feast will feel happy only after everything is completed, as the work is absorbing and exhausting (see Kuehling 2005: Ch. 8). A wide range of relatives can choose to contribute with produce, valuables and work, finding time to socialise with an even wider range of individuals and a valid reason to visit a wider range of places. Participating fully in mortuary feasting is a way to acquire status, but not everybody is inclined to work hard over several months. As in any society, internal politics are always at play, demotivating some villagers while pushing others to their highest level of performance.

\section{Posture, morals and emotions}

As elsewhere, in Dobu, a peaceful time lacking pain and worries makes people happy; the cool evening breeze after a hot day and the cuteness of toddlers are typical examples for this state. Being together with friends and close relatives, joking and laughing together constitute the private joy of happiness. In a more public sense, generosity and hospitality and the physical pleasure of consumption give evidence of the hosts' character and the guests' skills of self-discipline. The back is not an innocent body part in Dobu; it is linked to moral judgements and social benefits and serves as a metaphor for, and marker of, a person's qualities. It may be the underlying reason for gift-giving and provides significant rhetoric in kula negotiations. The release of mourning restrictions makes people happy, as they are allowed to quietly enjoy normal life again, just as the unexpected gift from a faraway kula partner can bring about a feeling of joy. 
Physical and psychic contentment are ideal states of being that are not easy to maintain in the small world of villagers, where conflicts are prone to live long and tensions are not easily resolved. To be happy in spite of everyday troubles gives evidence of a strong character-a back that is stiff and upright even under difficult conditions. A person who can maintain a straight back shows an ability to master negative feelings of greed, anger, laziness and arrogance, and appears to be blessed with a happy character. Such people are better neighbours, affines and exchange partners; they are good to have around.

The Austronesian body as a site of sociality has received increasing attention since the 1980s, but there is room for more inquiry, especially in the field of empathy, emotion and morality. Throop, in his study of pain in Yapese society in Micronesia (2010), has convincingly argued that a Eurocentric perspective of pain has often limited our understanding of the phenomenon. Suffering, in Yap and Dobu, can provide an opportunity to display one's virtue if it is shrugged off with a straight face or a smile. I believe the same is true for other emotions, including feelings of happiness and laziness. Throop proposes an ethnography of subjectivity in which temporality is:

an imperative that precedes the temporality of reflexive modes of understanding that are invested with the particularities of a given moral order, a particular theodicy, or a particular eschatology whether narratively, metaphorically, or practically conceived. (Throop 2010: 273)

As Throop has demonstrated, situating emotions in their moral context, in time and space, can provide empathetic representation and, ultimately, a better understanding of the underlying motivations of the people with whom we work.

Catherine Lutz, in her discussion of emotion in Ifaluk (Austronesianspeaking islanders of the central Caroline Islands in Micronesia), has demonstrated that an analysis of vernacular constructions of inner states provides a useful perspective, provided the researcher can empathetically 'pick up' the vibes and worries around them, and using vernacular terminology helps to frame thoughts and feelings in locally meaningful ways (1988: 216, 225). Anthropological fieldwork-'deep hanging out'together with some introspective analysis of the ethnographer's own emotional chartering, will reveal a wide array of understandings for our own terminology. The black box of emotions sits in a black box of our own assumptions, and both need to be handled with care. 
The invisible side of ethnography, while difficult to access, is nevertheless important for overall understanding. Austronesia, a sea of islands, is connected not only by the waves, but also by the wind. All living beings share island air - the ubiquitous breeze — transcending the boundaries of bodies and spreading the sounds and scents of life. Ghosts and magicians, witches and spirits travel on this breeze, adding to this emotional and moral space. These invisible beings are believed to have their own nua, which they may or may not be able to keep confined. Since yam roots are also endowed with nua, it is quite a crowded environment, and how much room the islanders take for themselves, how loud and tall they present themselves depend on their sophistication in self-discipline and silent suffering.

\section{References}

Bellwood, Peter, James J. Fox and Darrell Tryon (eds). 1995. The Austronesians: Historical and comparative perspectives. Canberra: The Australian National University.

Bolton, Lissant. 1999. 'Women, place and practice in Vanuatu: A view from Ambae'. Oceania 70(1): 43-55. doi.org/10.1002/j.1834-4461. 1999.tb02988.x.

Brenneis, Donald L. and Fred R. Myers (eds). 1984. Dangerous Words: Language and politics in the Pacific. New York: New York University Press.

Colson, Elizabeth. 2012. 'Happiness'. American Anthropologist 114(1): 7-8.

Dernbach, Katherine B. 2005. 'Popular religion: A cultural and historical study of Catholicism and spirit possession in Chuuk, Micronesia'. $\mathrm{PhD}$ dissertation. University of Iowa, Iowa City.

Dixon, J. W. n.d. Dobu/English Dictionary. Salamo, PNG: The United Church Salamo.

Dutton, Tom, Malcolm Ross and Darrell Tryon (eds). 1992. The Language Game: Papers in memory of Donald C. Laycock. Canberra: Pacific Linguistics. 
Edoni, Gail. 1989. Head and Shoulders, Knees and Toes. Ukarumpa, PNG: Summer Institute of Linguistics.

Falgout, Suzanne, Lin Poyer and Laurence M. Carucci. 2008. Memories of War: Micronesians in the Pacific war. Honolulu: University of Hawai' i Press.

Fox, James J. (ed.). 1993. Inside Austronesian Houses: Perspectives on domestic designs for living. Canberra: The Australian National University.

Fox, James J. 1995. 'Austronesian societies and their transformations'. In Peter Bellwood, James J. Fox and Darrell Tryon (eds) The Austronesians: Historical and comparative perspectives, pp. 214-28. Canberra: The Australian National University.

Fox, James J. 1997a. 'Genealogy and topogeny: Towards an ethnography of Rotinese ritual place names'. In James J. Fox (ed.) The Poetic Power of Place: Comparative perspectives on Austronesian ideas of locality, pp. 91-102. Canberra: The Australian National University.

Fox, James J. (ed.). 1997b. The Poetic Power of Place: Comparative perspectives on Austronesian ideas of locality. Canberra: The Australian National University.

Hau'ofa, Epeli. 1998. 'The ocean in us'. The Contemporary Pacific 10(2): 392-410.

Hereniko, Vilsoni. 2000. 'Indigenous knowledge and academic imperialism'. In Robert Borofsky (ed.) Remembrances of the Past: An invitation to remake history, pp. 78-91. Honolulu: University of Hawai'i Press.

Hess, Sabine. 2009. Person and Place: Ideas, ideals and the practice of sociality on Vanua Lava, Vanuatu. New York: Berghahn Books.

Huang, Shuanfan. 2002. 'Tsou is different: A cognitive perspective on language, emotion, and body'. Cognitive Linguistics 13(2): 167-86. doi.org/10.1515/cogl.2002.013.

Jackson, Michael. 1995. At Home in the World. Durham, NC: Duke University Press.

Johnston, Barbara Rose. 2012. 'On happiness and transformative change'. American Anthropologist 114(1): 15-16. 
Kahn, Miriam. 1996. 'Your place and mine: Sharing emotional landscapes in Wamira, Papua New Guinea'. In Steven Feld and Keith H. Basso (eds) Senses of Place, pp. 167-96. Santa Fe, NM: School of American Research Press.

Kasaipwalova, John. 1974. "Modernising” Melanesian society: Why, and for whom?' In Ron May (ed.) Priorities in Melanesian Development, pp. 451-4. Canberra: The Australian National University and University of Papua New Guinea.

Kuehling, Susanne. 1996. 'Gwasa: eine soziale Krankheit [Gwasa: A social disease]'. Invoemagazin 11:29-30.

Kuehling, Susanne. 2005. Dobu: Ethics of exchange on a Massim island, Papua New Guinea. Honolulu: University of Hawai'i Press.

Kuehling, Susanne. 2014. 'The converted war canoe: Cannibal raiders, missionaries and pax Britannica on Dobu Island, Papua New Guinea'. Anthropologica 56(2): 269-84.

Kuehling, Susanne. 2017a. 'A fat sow named Skulf: "Expensive" words in Dobu Island society'. In Elisabetta Gnecchi-Ruscone and Anna Paini (eds) Tides of Innovation in Oceania: Value, materiality and place, pp. 193-224. Canberra: ANU Press. doi.org/10.22459/TIO.04.2017.

Kuehling, Susanne. 2017b. "'We die for kula": An object-centred view of motivations and strategies in gift exchange'. Journal of the Polynesian Society 126(2): 181-208.

Lithgow, Daphne (ed.). 1984. Dobu-English Dictionary. Ukarumpa, PNG: Summer Institute of Linguistics.

Lutz, Catherine A. 1988. Unnatural Emotions: Everyday sentiments on a Micronesian atoll and their challenge to Western theory. Chicago: University of Chicago Press.

Macintyre, Martha. 1995. 'Violent bodies and vicious exchanges: Personification and objectification in the Massim'. Social Analysis 37: 29-43.

Mosko, Mark. 2009. 'The fractal yam: Botanical imagery and human agency in the Trobriands'. Journal of the Royal Anthropological Institute 15(4): 679-700. doi.org/10.1111/j.1467-9655.2009.01579.x. 
Nordstrom, Carolyn. 2012. 'Happiness (is not a warm gun)'. American Anthropologist 114(1): 13-14.

Pawley, Andrew. 1985. 'Proto-Oceanic terms for "person": A problem in semantic reconstruction'. In Veheeta Z. Acson and Richard L. Leed (eds) For Gordon H. Fairbanks, pp. 92-105. Oceanic Linguistics Special Publications No. 20. Honolulu: University of Hawai'i Press.

Pawley, Andrew and Malcolm Ross. 1995. 'The prehistory of Oceanic languages: A current view'. In Peter Bellwood, James J. Fox and Darrell Tryon (eds) The Austronesians: Historical and comparative perspectives, pp. 39-74. Canberra: The Australian National University.

Rensel, Jan and Margaret Rodman (eds). 1997. Home in the Islands: Housing and social change in the Pacific. Honolulu: University of Hawai'i Press.

Ross, Malcolm, Andrew Pawley and Meredith Osmond (eds). 2003. The Lexicon of Proto Oceanic. Volume 2: The culture and environment of ancestral Oceanic society. The physical environment. Canberra: The Australian National University.

Strathern, Marilyn. 1988. The Gender of the Gift: Problems with women and problems with society in Melanesia. Berkeley, CA: University of California Press

Throop, C. Jason. 2010. Suffering and Sentiment: Exploring the vicissitudes of experience and pain in Yap. Berkeley, CA: University of California Press.

Weiner, Annette B. 1984. "From words to objects to magic: "Hard words" and the boundaries of social interaction'. In Donald L. Brenneis and F. R. Myers (eds) Dangerous Words, pp. 161-91. New York: New York University Press. 
This text is taken from Expressions of Austronesian Thought and Emotions, edited by James J. Fox, published 2018 by ANU Press, The Australian National University, Canberra, Australia.

doi.org/10.22459/EATE.04.2018.07 